\title{
Perubahan Bervariasi dalam Ekranisasi Manga Death Note Karya Tsugumi Ohba dan Takeshi Obata ke dalam Drama Death Note Karya Inomata Ryuichi
}

\author{
Ni Wayan Nadia Setya Wati, Silvia Damayanti, Ni Luh Putu Ari Sulatri \\ Program Studi Sastra Jepang, Fakultas Ilmu Budaya, Universitas Udayana \\ Denpasar, Bali-Indonesia \\ [nadyasetya2015@gmail.com],[silvia_damayanti@unud.ac.id], [ari_sulatri@unud.ac.id]
}

\begin{abstract}
Abstrak
Penelitian ini berjudul "Perubahan Bervariasi dalam Ekranisasi Manga Death Note Karya Tsugumi Ohba dan Takeshi Obata ke dalam Drama Death Note Karya Inomata Ryuichi”. Tujuan penelitian ini adalah memberi pemahaman terhadap ekranisasi dengan sumber berupa manga terkait perubahan pada unsur instrinsik. Metode penelitian yang digunakan adalah metode deskriptif kualitatif. Sumber data yang digunakan dalam penelitian ini adalah Manga Death Note karya Tsugumi Ohba \&Takeshi Obata dan Drama Death Note karya Inomata Ryuichi. Teori yang digunakan dalam penelitian ini adalah Teori Ekranisasi yang dikemukakan oleh Eneste dan Teori Struktural oleh Nurgiyantoro. Hasil penelitian ini menunjukkan bahwa terdapat perubahan pada unsur intrinsik yang terdapat pada manga ke dalam drama. Perubahan tersebut berupa perubahan bervariasi yang terjadi pada alur, tokoh, dan latar tempat. Perubahan bervariasi ini bertujuan mengubah cerita, suasana, kesan, peranan, dan menyesuaikan biaya produksi.
\end{abstract}

Kata kunci : Ekranisasi, drama televisi, dan Manga.

\begin{abstract}
This research is entitled "Variety Changes in the Ecranization of the Death Note Manga by Tsugumi Ohba and Takeshi Obata into the Death Note Drama by Inomata Ryuichi". The purpose of this study is to provide an understanding of ecranization with sources in the form of manga related to changes in intrinsic elements. The research method used is descriptive qualitative method. The data sources used in this study are the Manga Death Note by Tsugumi Ohba \& Takeshi Obata and Drama Death Note by Inomata Ryuichi. The theory used in this research is Ecranization Theory proposed by Eneste and Structural Theory by Nurgiyantoro. The results of this study indicate that there is a change in the intrinsic elements contained in the manga into drama. These changes are in the form of varied changes that occur in the plot, characters, and setting of the place. These varied changes aim to change the story, atmosphere, impression, role, and adjust production costs.
\end{abstract}

Keywords: Ecranization, television drama, and Manga.

\section{Pendahuluan}

Penciptaan suatu karya sastra dapat dilakukan melalui ekranisasi atau mengubah bentuk karya teks ke layar. Ekranisasi merupakan suatu proses perlayarputihan, pemindahan, atau pengubahan sebuah karya sastra kedalam bentuk film (Eneste, 1991:60). Banyak karya sastra di Jepang, yang sudah diekranisasi untuk diperkenalkan 
secara luas, karya sastra tersebut berupa manga yang diekranisasikan menjadi dorama atau drama televisi.

Dorama adalah program televisi yang merupakan bahan pokok dari televisi Jepang yang disiarkan setiap hari. Beberapa dorama merupakan hasil dari ekranisasi manga dengan berbagai seri seperti romansa, komedi, horror, dan lain-lainnya. Hingga saat ini banyak karya sastra yang telah mengalami ekranisasi ke dalam bentuk drama, salah satunya adalah Manga Death Note karya Tsugumo Ohba dan Takeshi Obata yang diekranisasikan ke dalam drama karya Inomata Ryuichi.

Berdasarkan latar belakang, yang menjadi rumusan masalah dari penelitian ini yaitu bagaimanakah perubahan bervariasi pada ekranisasi manga ke dalam drama Death Note. Penelitian ini memiliki tujuan umum dan tujuan khusus. Pada penelitian ini tujuan umumnya yaitu agar dapat lebih memahami karya sastra serta dapat menambah wawasan penelitian pada bidang sastra. Tujuan khususnya adalah agar dapat mengetahui perubahan bervariasi pada ekranisasi manga ke dalam drama Death Note.

\section{Metode Penelitian}

Pada penelitian ini sumber data berupa yang manga Death Note dari volume 1-12 dan drama Death Note dari episode 1-11. Pada metode pengumpulan data digunakan metode studi kepustakaan (Ratna, 2004:39). Metode simak dan catat juga digunakan untuk mengumpulkan data dari kedua sumber. Metode deskriptif analisis (Ratna,2004:53) digunakan pada analisis data. Selanjumya menggunakan metode informal (Ratna, 2004:50) pada penyajian hasil analisis data.

\section{Kajian Paustaka}

Penelitian terkait alih wahana dari manga ke dalam film live action telah dilakukan oleh Jayanti (2020) dan penelitian yang dilakukan oleh Jayanti menjadi acuan pada penelitian ini. Penelitian Jayanti dilakukan agar dapat menambah wawasan mengenai perubahan sastra populer Jepang menjadi film live action. Pada penelitian ini juga menggunakan sumber yang sama yaitu manga diekranisasikan ke dalam bentuk drama. Pada penelitian ini menghasilkan penciutan dan penambahan yang terjadi pada 
ekranisasi manga Death Note ke dalam drama selain itu, juga ditemukan perubahan bervariasi. Namun pada penelitian ini hanya berfokus pada alasan atau penyebab terjadinya perubahan bervariasi pada kedua sumber data yang mengalami ekranisasi dengan hasil analisis yang dibutikan dengan data.

\section{Hasil dan Pembahasan}

Pada penelitian yang dilakukan dalam ekranisasi manga Death Note ke dalam drama diperoleh hasil yaitu terjadinya penciutan, penambahan, dan perubahan bervariasi. Namun pada pembahasan berikut hanya membahas menggenai perubahan bervariasi yang terjadi pada ekranisasi manga Death Note ke dalam drama Death Note.

\subsection{Perubahan Bervariasi}

Perubahan bervariasi terjadi agar dapat menyajikan hasil yang berbeda dari karya yang mengalami ekranisasi dengan diiringi berbagai alasan tertentu. Berdasarkan hal yang telah dijelaskan pada hasil sebelumnya, berikut merupakan salah satu contoh perubahan bervariasi yang dilakukan agar dapat membuat cerita semakin menarik pada drama Death Note. Salah satu contoh adegan yang divariasikan karena alasan tersebut adalah peristiwa ketika kemunculan Near dan Mello pada manga dan drama. Berikut merupakan perbandingan peristiwa pada manga dan drama Death Note.

$$
\begin{aligned}
& \text { ロジャー：メロ } \\
& \text { そしてニア私の部屋へ } \\
& \text { ニア : はい } \\
& \text { メロ：何だい?ロジャー } \\
& \text { ロジャー：Lが死んだ } \\
& \text { (デスノート } 7,2003: 149-150 \text { ) } \\
& \text { Rojā : :Mero soshite nia watashi no heya e } \\
& \text { Nia : Hai } \\
& \text { Mero : Nan dai? Rojā } \\
& \text { Rojā : L ga shinda } \\
& \text { Roger : Mello } \\
& \text { (Desu Nōto 7, 2003: } 149 \text { - 150) } \\
& \text { Dan kau, Near, tolong ke ruanganku. } \\
& \text { Near : Ya } \\
& \text { Mello : Ada apa Roger? } \\
& \text { Roger : L tewas }
\end{aligned}
$$




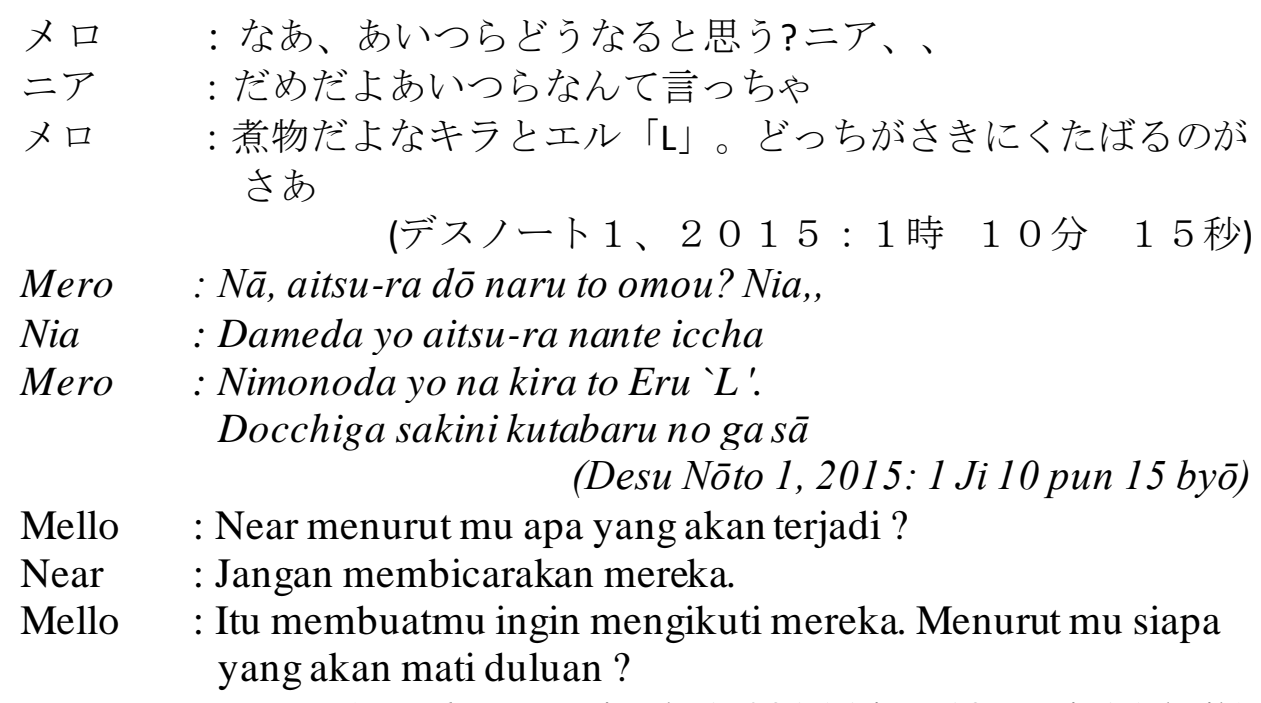

(Death Note episode 1, 2015:1 jam 10 menit 15 detik)

Gambar (1)

Peristiwa pada manga

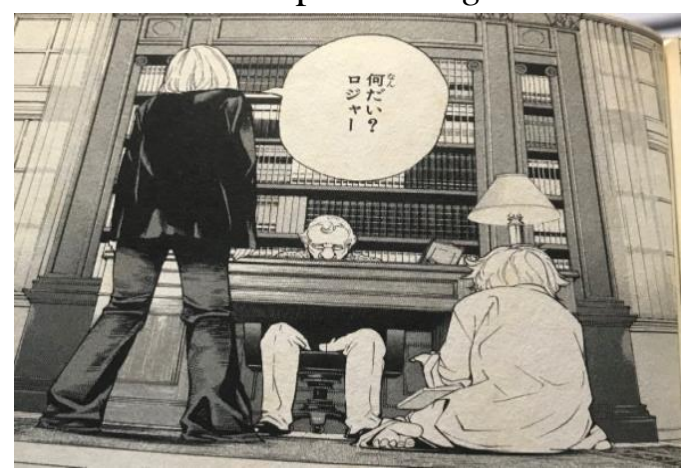

Gambar (2)

Peristiwa pada drama

Sumber: Death Note episode 1, 2015:1 jam 10 menit 15 detik

Data (1) dan (2) merupakan kutipan dari masing-masing sumber data yang dibandingkan beserta dengan gambar (1) dan (2). Variasi peristiwa tersebut dilakukan agar membuat cerita menjadi semakin menarik dibandingkan dengan cerita pada manga.

Variasi yang ditunjukkan melalui kedua data di atas juga mengarah kepada tokoh dan latar terjadinya kemunculan Near dan Mello. Pada data (1) menunjukkan bahwa kemunculan tokoh Near dan Mello dimunculkan setelah kematian L. Kedua tokoh tersebut pada manga tidak dibuat memiliki keterlibatan dengan tokoh L kemudian pada gambar (1) menunjukkan tokoh Near dan Mello merupakan orang yang berbeda dan lokasi disebuah ruangan ketika Near dan Mello dipanggil untuk ditugaskan menggantikan posisi L yang telah meninggal. Namun pada data (2) ditunjukkan bahwa 
Near dan Mello telah mengetahui bahwa L sedang berjuang untuk mengalahkan Kira. Tokoh Near dan Mello diperlihatkan pada drama menjadi nantinya akan terlibat dengan L pada penyelidikan kasus Kira maka dari itu dari awal kedua tokoh ini dimunculkan lalu pada gambar (2) menunjukkan tokoh Near sedang bersama dengan sebuah boneka yang bernama Mello dan lokasi pada peristiwa tersebut terjadi di ruangan gedung yang besar. Berdasarkan perbandingan tersebut variasi yang dilakukan sutradara agar dapat membuat cerita menjadi semakin menarik.

\section{Simpulan}

Dalam ekranisasi menghasilkan perubahan yang terjadi pada manga yang diekranisasikan ke dalam drama. Perubahan tersebut terjadi akibat adanya perubahan bervariasi yang terjadi dalam ekranisasi manga Death Note ke dalam drama. Perubahan bervariasi tersebut terjadi pada alur, tokoh, dan latar tempat. Hal tersebut terjadi pada alur dilakukan agar dapat merubah suasana dan membuat cerita menjadi semakin menarik. Pada tokoh mengalami perubahan bervariasi karena karakter mengalami variasi cerita, merubah kesan terhadap penonton, menjadi pendukung terjadinya suatu peristiwa, dan variasi pada peranan suatu tokoh. Kemudian perubahan bervariasi pada latar tempat terjadi karena mengalami variasi cerita dan biaya produksi.

\section{Daftar Pustaka}

Damayanti, Silvia.2016. "Alih Wahana Buku Cerita Bergambar Ke Dalam Komik Sebagai Sarana Pelestarian Cerita Rakyat Jepang ”. Denpasar:Universitas Udayana

Eneste, Pamusuk. 1991. Novel dan Film. Flores : Nusa Indah

Hawarismi , Fatih Hikam Al. 2017. "Analisis Proses Alih Wahana Dari Light Novel Ke Anime GATE : Jietai Kanochi Nite Kaku Tatakaeri” (Skripsi). Semarang : Universitas Diponegoro.

Jayanti, Tri Ni Komang. 2020 "Alih Wahana Manga Ao Haru Ride Karya Sakisaka Io ke dalam Film Live Action Karya Sutradara Miki Takahiro" (Skripsi) Denpasar: Universitas Udayana.

Nurgiyantoro, Burhan. 2007. Teori Pengkajian Fiksi.Yogyakarta : Gajah Mada University Press. 
Padmiani, Ni Luh Gde Diah, Silvia Damayanti, and Ni Luh Kade Yuliani Giri. "Alih Wahana Cerita Rakyat Momotaro dari Ehon Menjadi Kashidan Anime". Ratna, N.K. 2004. Teori, Metode dan Teknik Penelitian Sastra. Yogyakarta : Pustaka Pelajar 